\title{
正弦波状の起伏地形における波動伝播の解析 \\ ANALYSIS OF SEISMIC WAVE PROPAGATION IN A GROUND WITH SINUSOIDAL-SHAPED SURFACE IRREGULARITY
}

\author{
川上英二*1, 茂木秀則*2，福原幸司*3 \\ Hideji KAWAKAMI, Hidenori MOGI and Koji FUKUHARA
}

\begin{abstract}
Seismic responses of a ground with various types of sinusoidal-shaped irregularity were evaluated by using the boundary element method and analyzed based on "scattered-wave contribution". The examination of the numerical results revealed the following: 1) the response at the trough varies sharply with frequency whereas the response at the peak shows large amplification over a wide frequency range; 2 ) the predominant frequencies at the trough depend on the amplitude of the surface irregularity and do not depend on the number of fluctuations of the ground; and 3) these characteristics can be understood as the results of the interference of scattered waves coming from the irregular surface.
\end{abstract}

Keywords: irregular topography, scattered wave, SH wavefield, boundary element method 起伏, 散乱波, SH 波動場, 境界要素法

\section{1 はじめに}

不整形地盤によって生じる特異な地震応答は多くの研究者に注 目され，主に数值解析に基づいたパラメトリックな研究が行われて (る ${ }^{1), 2)}$. 例えば，地震灾答に及ぼす不整形基盤の影響3)-7) や埋没 盆地の影響8) などが検討されており，さらに最近では，1995 年兵 庫県南部地震の帯状の強震域の発生原因として平野端部の不整形 境界の影響が指摘されており，多くの数值解析が行われている(例 えば文献 9).

一方, 1971 年 San Fernando 地震の観測事例などから，地表面 の起伏が地震応答に及ぼす影響についても注目され，同様に地震応 答解析が行われている. たとえば， Boore は Pacoima ダム周辺の 急峻な地形を対象に差分法を用いた検討を行い，山頂付近では大 きな忍答を示ずことなどを指摘している ${ }^{10)}$ 。さらに地表面の起伏 の影響を検討した研究として, 崖地形 ${ }^{11)-14)}$, 半円形や三角形の断

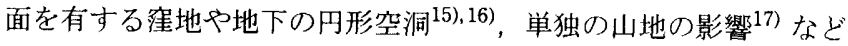
が挙げられる。しかしながらここれらの研究の多くが数值的に求 めた振動数応答関数や時刻歴波形に基づいて地震忘答の特徵を論 じる手法を用いており, 複雑な応答を示すメカニズムについては依 然として不明な点が多く残されている。 また，二れらの研究の多 くが山岳部等に見られる比較的急峻で局地的な地形の起伏を対象 としており，大都市が立地する平野部にも多く存在するような比較
的なだらかで連続する起伏の影響は検討されていない。これらの 起伏地形は，例えば，台地において平行する河川によって形成され た浸食谷などの他, 風化, 堆積作用が働く大地は, 平坦に見えても よく見ればなだらかな起伏が続く地形であることが多い，そして， このような起伏によって地表面の地震応答が影響を受けるならば, 影響の生じる条件とその程度を把握しておくことは重要である。さ らに, 得られた知識に基づいて, 起伏地形を一見して地震応答の 概略が推測できるならば，地震被害の想定や検討に際して有用で あろう。

そこで, 本研究では正弦波形の起伏を有する均質地盤を取り上 げ, 起伏の高さを変えた場合と, 起伏の数を変えた場合の振動数态 答関数の変化に着目して地震応答解析を行った. もとより, 実地盤 では篇密に正弦波形状（高さ, 波長が一定）の起伏が存在するわ けではない, しかし, 特定の地盤を想定せずに, 少ないパラメー 夕を用いて起伏一般の影響を検討する際には，実際の起伏に近い 形状を与える関数として正弦波形を用いることは合理的であるう. 本論文では，正弦波の数の違いにより起伏の長さを表し，局地的 には（例えば凸凹一つでは）無視し得る地形の影響が, 多数の起伏 が連続することにより問題となることがあるのか否かを検討した。 このため, 一つの典型的な例として，正弦波形状の起伏が連続す る地盤の検討も行った。

\footnotetext{
*1 埼馬大学地圈科学研究センター 教授・工博

*2 埼太大学:工学部建設工学科 講師・博上(工学)

*3 日本電子計算㑣) 修士(工学 研究当時 埼王大学理工学研究科
}

\footnotetext{
Prof., Geosphere Research Institute, Saitama University, Dr. Eng. Lecturer, Dept. of Civil and Environmental Engineering, Saitama University,
Dr. Eng.

Japan Information Processing Service Co., Ltd., Ex-student of Saitama University, M. Eng.
} 


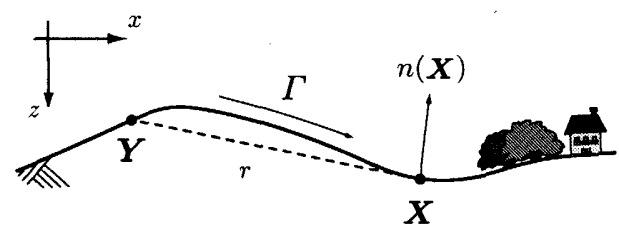

図 1 地形モデルと座標系

解析は SH 波動場にお㤝境界要素法を用い, 既往の多くの研 究と同様に地表面の各地点での応答関数を求めるとともに，ホイ ヘンスの原理に基べいて算定した散乱波の波面の位置や，新たに 導入した, 境界要素行列から得られる散乱波の「寄与分布」に基つ いて, 地表面の忘答特性が起伏の高さ, 数および谷底, 山頂など条 件・場所により異なるメカニズムを検討した。これらの結果から， 谷底では振動数により応答関数が明瞭な極小值と極大值を示すの に対し，山頂では振動数にあまり依存せずに一様に大きい值を示す ことを指摘した，さらに，谷底の态答関数において，起伏の高さを 増加させた場合に忘答関数のピークを与える振動数（基本振動数） が滅少するのに対し，起伏の数を増加させると基本振動数は殆ど 変化せずに, 応答関数のピークが鋭い形状に変化することなどを 指摘した。 また，散乱波の奇与分布の検討から，それぞれの地点に 特徵的な忘答関数は, 起伏の特定の部分からの散乱波が干涉し增 幅された結果であることを示した.

なお，なだらかであるが連続する起伏地形におけり，境界要素 法とホイヘンスの定理に基づいた波動伝播や干涉の現象の検討は 著者の知る限りでは既往の研究に存在せず，これらの点は著者らの 独自のものであると考えている.

\section{2 境界要素法に基づく散乱波の寄与分布の定式化}

2.1 境界積分方程式の荋出 ${ }^{18)-20)}$

図1のような，起伏を有する均質な半無限地盤にお㤝る $\mathrm{SH}$ 波 動場を考える。このとき振動数領域の方程式として，次式のハル ツホルム方程式が得られる.

$$
\left\{\nabla^{2}+k_{\beta}^{2}\right\} u(\boldsymbol{X})=0, \quad k_{\beta}=\omega / \beta
$$

ここで, $u(\boldsymbol{X})$ は弾性体内の任意の点 $\boldsymbol{X}=(x, z)$ における変位, $\omega$ は角振動数， $\beta$ はS 波速度， $k_{\beta}$ はS 波の伝播方向の波数である. 式 (1)にグリーンの定理を適用すると, 自由表面が唯一の境界で あることから，二重層ポテンシャルのみを積分項とする次式の境界 積分方程式が得られる.

$$
c(\boldsymbol{Y}) u(\boldsymbol{Y})+\text { v.p. } \int_{\Gamma} q^{*}(\boldsymbol{X}, \boldsymbol{Y}) u(\boldsymbol{X}) d \Gamma(\boldsymbol{X})=v(\boldsymbol{Y})
$$

ここで $v(\boldsymbol{Y})$ は境界 $\Gamma$ 上の点 $\boldsymbol{Y}$ における入射波による変位, $c(\boldsymbol{Y})$ は境界の $\boldsymbol{Y}$ に扮ける形状によって決まる值であり，境界が滑らか であるとき $1 / 2$ である．また， $q^{*}(\boldsymbol{X}, \boldsymbol{Y})$ 沬表面力の基本解（全無 限解・具体形は式 (4) 参照) であり, v.p. は $\boldsymbol{X}=\boldsymbol{Y}$ の場合に生じ る特異点に関して主値積分によって積分値を評価することを表す。

\section{2 一定要素を用いた境界樌分方程式の離散化 ${ }^{18)-20)}$}

本研究では境界積分方程式を一定要素を用いて離散化を行った。 境界 $\Gamma$ を $J$ 個の境界要素 $\Gamma_{j},(j=1, \ldots, J)$ で分割, 近似する. さらに,一つの境界要素 $j$ 上の変位を一定値と見なし，この值を境 界要素 $j$ の中点の変位 $u\left(\boldsymbol{X}_{j}\right)$ で代表させる。これらの近似によっ て式 (2) を離散化すると, 次式のような連立一次方程式の形に表す

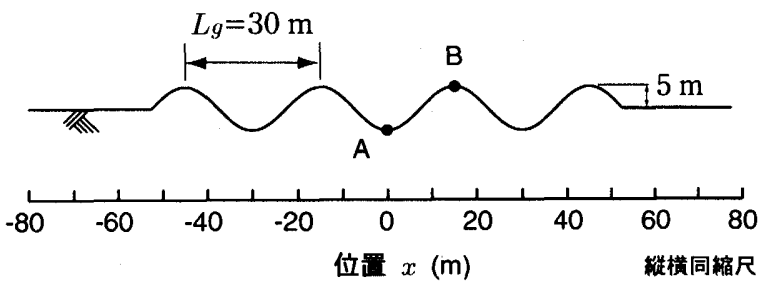

図 23.5 波正弦波型地形モデル（標準モデル）

ことができる.

$$
\boldsymbol{v}=\boldsymbol{H} \boldsymbol{u}
$$

ここで, $\boldsymbol{u}$ は全ての境界要素の応答変位 $u\left(\boldsymbol{X}_{j}\right)$ を, $\boldsymbol{v}$ は入射波に よる変位 $v\left(\boldsymbol{X}_{j}\right)$ の節点值を並べた $J$ 次元ベクトル, $\boldsymbol{H}$ は次式に 示す $h_{j m},(m=1, \ldots, J)$ を要素とする $J$ 次元の正方行列である.

$$
\begin{aligned}
h_{j m} & =\int_{\Gamma_{m}} q^{*}\left(\boldsymbol{X}, \boldsymbol{Y}_{j}\right) d \Gamma(\boldsymbol{X})+c\left(\boldsymbol{Y}_{j}\right) \delta_{j m} \\
& =\int_{\Gamma_{m}} \frac{i k_{\beta}}{4} H_{1}^{(2)}\left(k_{\beta} r\right) \frac{\partial r}{\partial \boldsymbol{n}(\boldsymbol{X})} d \Gamma(\boldsymbol{X})+\frac{1}{2} \delta_{j m}
\end{aligned}
$$

ここで, $r$ は $\boldsymbol{X}, \boldsymbol{Y}_{j}$ 間の距離 $\left|\boldsymbol{X}-\boldsymbol{Y}_{j}\right|, n(\boldsymbol{X})$ は $\boldsymbol{X}$ における 地表面の法線ベクトル， $\delta_{j m}$ はクロネッカーーのデルタである。 な お， $j=m$ の場合には式 (4) の積分は前述のように主值積分であ るが，“定要素を用いた境界要素法では $\boldsymbol{X}-\boldsymbol{Y}_{j}$ と $n(\boldsymbol{X})$ が直交 するため， $\partial r / \partial \boldsymbol{n}=0$ となる.このため，式(4)の右辺の積分值 は0となり， $h_{j j}=1 / 2$ が得られる.

\section{3 境界要素行列から得られる散乱波の寄与分布}

地表面が平坦である場合には常に $\partial r / \partial \boldsymbol{n}(\boldsymbol{X})=0$ となるため， 式 (4) が

$$
\boldsymbol{H}=\frac{1}{2} \boldsymbol{E}
$$

が得られる。ここで $\boldsymbol{E}$ は単位行列を表す，従って，地表面が平坦 である場合の地表面の節点変位 $\boldsymbol{u}^{f}$ は

$$
\boldsymbol{u}^{f}=\boldsymbol{H}^{-1} \boldsymbol{v}^{f}=2 \boldsymbol{E} \boldsymbol{v}^{f}
$$

で与えられ，入射波の振幅の 2 倍の応答值を示す。ここで， $\boldsymbol{v}^{f}$ は 平坦な地表面の各地点での入射波の振幅（すなわち，起伏に伴う 位相の差違が生じない) をべクトル化したものである.

一方，地表面に起伏がある場合，式 (3) の連立方程式を解くこと で未知の節点変位 $\boldsymbol{u}$ が得られるが，さらに次式のように変形する ことができる。

$$
\begin{aligned}
\boldsymbol{u}= & \boldsymbol{H}^{-1} \boldsymbol{v}=2 \boldsymbol{E} \boldsymbol{v}+\boldsymbol{S} \boldsymbol{v}=\boldsymbol{u}^{f^{\prime}}+\boldsymbol{u}^{s} \\
& \boldsymbol{S}=\boldsymbol{H}^{-1}-2 \boldsymbol{E} \\
& \boldsymbol{u}^{s}=\boldsymbol{S} \boldsymbol{v}
\end{aligned}
$$

ここで，式 (7) 中の $\boldsymbol{u}^{f^{\prime}}$ は入射波の振幅が $\boldsymbol{v}$ で与えられる場合の 平坦な地表面の節点変位, また, $\boldsymbol{u}^{s}$ は地形の起伏に起因する散乱 波による項に相当し, 式 (9) の関係から， $\boldsymbol{S}$ の $j m$ 成分は第 $m$ 要 素に入射した波動が第 $j$ 要素に与える散乱波の寄与を表すことが わかる.

しかし，それぞれの境界要素に入射される波動のエネルギーは 境界要素の長さによって変化してしまうため, $S$ の要素の単純な 比較によって散乱波の寄与の大小を論じることはできない. また， 起伏の各点から到来する散乱波が重社合わせられた全体の寄与を考 える場合，起伏に伴う入射波の位相の違いを考慮する必要がある。 

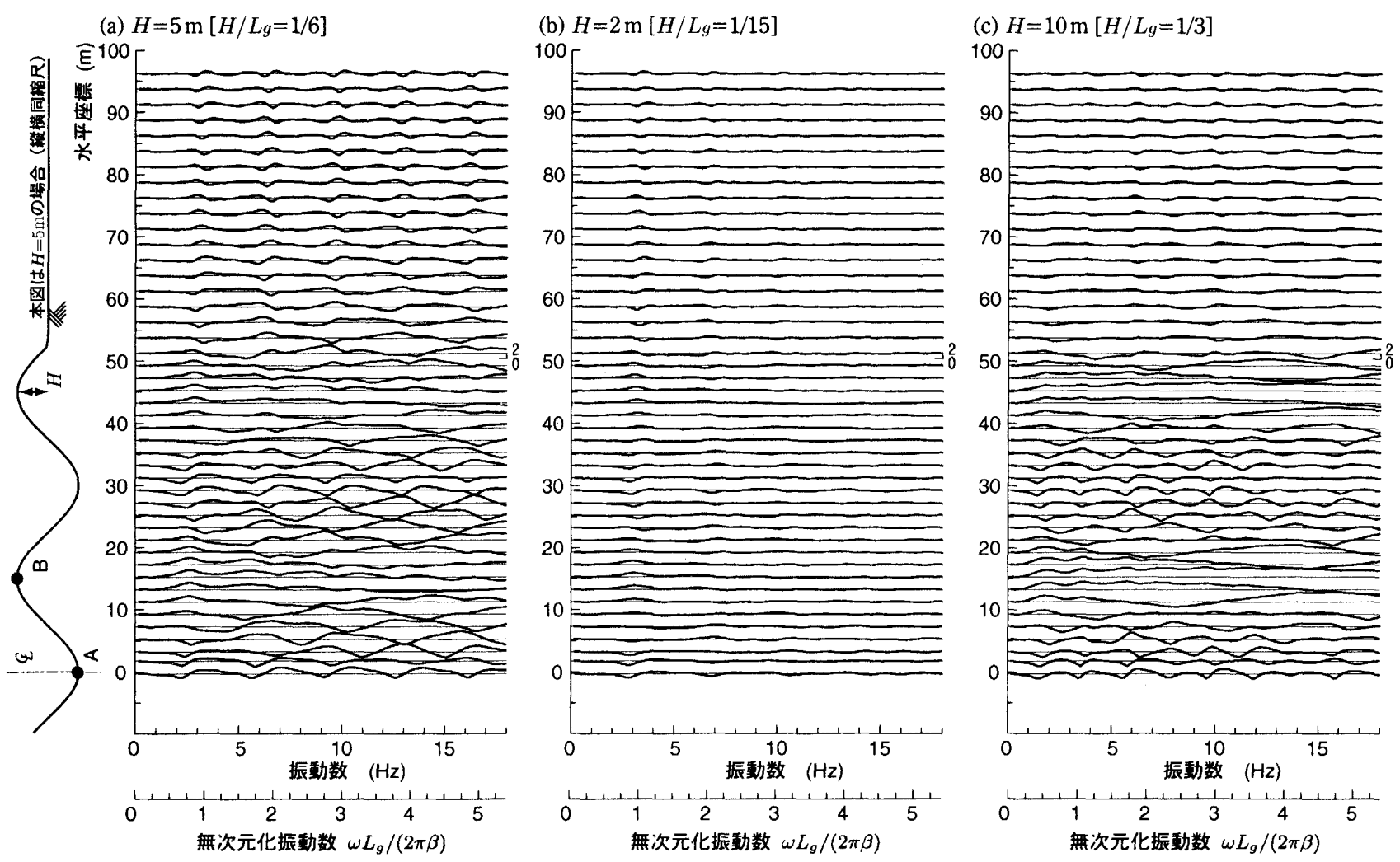

図 3 地表面の各地点の振動数応答関数
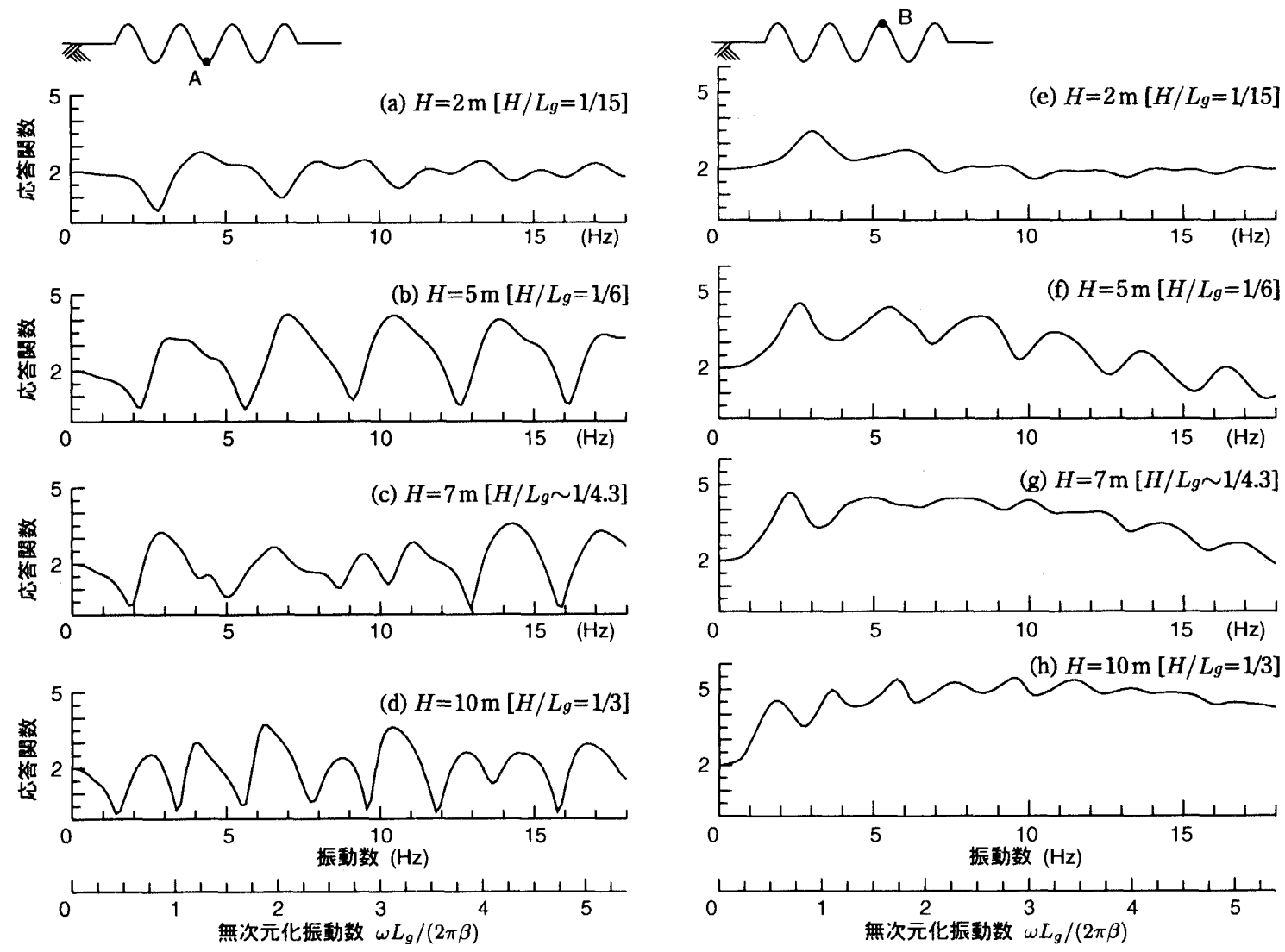

図 4 起伏の高さの違いによる振動数応答関数の変化 $[(\mathrm{a}) \sim(\mathrm{d})$ 谷底 $(\mathrm{A}$ 点 $) ，(\mathrm{e}) \sim(\mathrm{h})$ 山頂 $(\mathrm{B}$ 点 $)]$ 
このため本研究では，散乱波の寄与分布の算定に際して， $S_{j m}$ を 入射波の作用する境界要素の長さ $d L_{m}$ で除し，入射波の複素振幅 を掛けた単位長さ当たりの寄与 $\hat{S}_{j m}$ を用いた.

$$
\hat{S}_{j m}=S_{j m} v_{m} / d L_{m},\left|v_{m}\right|=1
$$

\section{3 解析で用いた地形モデル}

本研究で用いた地形モデル（標準モデル）を図 2 に示す。まず, 高さ $5 \mathrm{~m}$ (片振幅)，波長 $30 \mathrm{~m}$ の正弦波 3.5 波分の起伏を中央に 配置し, 両端を平坦とした地形モデルを標準モデルとして設定し た. そして, 起伏の高さを $2 \mathrm{~m} \sim 10 \mathrm{~m}$ に変化させた場合と, 高さ を $5 \mathrm{~m}$ に固定して起伏の数を変化させた場合について解析を行っ た. また, 後述するように, 起伏地形のうち特に谷底の点と山頂の 点が特徵的な応答を示すため，地形モデル中央の谷底を $\mathrm{A}$ 点，を の右隣の山頂を $\mathrm{B}$ 点とした。ただし，本論文では平野部において も一般的に存在するような，図 2 のような波長，高さ共に小さい （数 $\mathrm{m}$ 数十 $\mathrm{m}$ ）凹凸がある場合を主な対象にしておう，山岳地带 のいわゆる山，谷だけを扱っているものではない. しかし，ここで は簡単のために凹凸の頂点をそれぞれを谷底，山頂と称している。

なお，本研究で用いた全ての地形モデルにおいて S 波速度 $\beta$ を $100 \mathrm{~m} / \mathrm{s}$ とし，また，入射波は全て単位振幅の平面波を鉛直入射才 るものとした。

\section{4 起伏の高さが地震応答に与える影㱖 \\ 4.1 応答関数の概钼}

図 3 は地表面上の各地点に㧍汁る态答関数を上下に並べて示し たもので, 地形モデルの対称性から $x \geq 0$ の念答関数の奴を示し ている. 図の縦軸は各地点の水平位置を表し, 各地点の心答関数 の0座標を，各地点の水平位置に命わせてブロットしている。韦 た，それぞれの念答関数には基淮となる20值に細線がらかれて

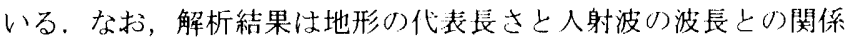
に基づく無次元化表現を用いて整理すると一般性が高まる。この ため，応答関数の振動数軸には起伏の波長 $L_{g}, \mathrm{~S}$ 波速度 $\beta$ で無次 元化した振動数 $\omega L_{g} /(2 \pi \beta)$ を示寸副尺を付けた。

起伏の高さが $5 \mathrm{~m}$ の標準モデルの場合（図 3 (a)）を見ると，谷 や山頂, 中腹の斜面部分など, 地形ごとに特徽的な伈答関数を示す ことがわかる．特に興味哚く思われるのは，谷の产答関数が振動 数に強く依存して複雑な形状を示すのに対して，山頂に近づくに つれて振動数依存性が弱くなり, 広い振動数の範囲 $(0 \sim$ 約 $10 \mathrm{~Hz})$ で一様に 2 以上の大きな态答を示すことである.

図 3(b) は起伏の高さが $2 \mathrm{~m}$ の場合の忘答関数を示寸。この場合, 不整形性の影響が小さく，振動数が $2 \sim 4 \mathrm{~Hz}$ の場合にわずかなが ら不整形性の効果が認められる程度である。一方, 図 $3(\mathrm{c})$ の起伏 の高さを $10 \mathrm{~m}$ とした場合を見ると，図 3(b) の場合と同じように 全体的な傾向は図 3 (a) と同じとも言えるが，山頂以外の多くの地 点で応答関数の山谷の数が増加しており, 応答関数がより強く振動 数に依存するように変化することがわかる，一方，不整形部分の 応答関数の值は起伏の高さが $5 \mathrm{~m}$ の場合に比べて多少大きな值を 示すが, 起伏の高さの違い（2 倍）ほどは顕著には変わらないこと がわかる。

\section{2 起伏の高さの変化に伴う谷底と山頂の応答関数の変化 4.2.1 谷底での応答関数}

図 4 は特徵的な形状を示寸谷底（A 点）と山頂（B 点）の态答関 数を示したもので，(a) (d) は起伏の高さを $2,5,7,10 \mathrm{~m}$ と変化
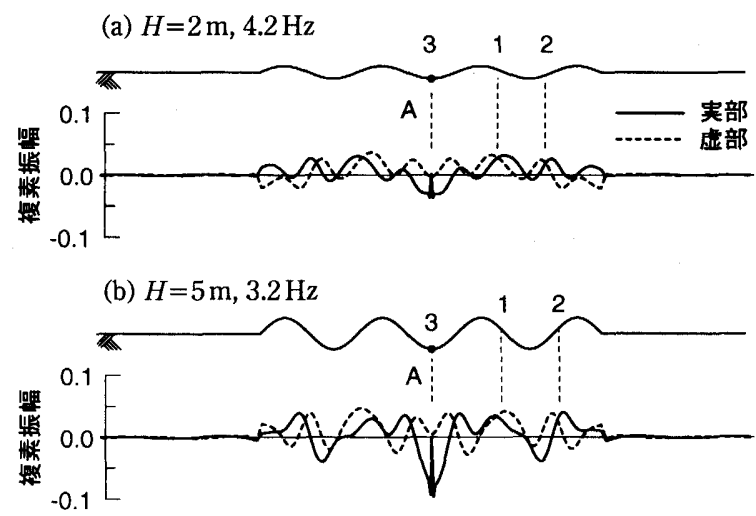

(c) $H=10 \mathrm{~m}, 2.5 \mathrm{~Hz}$

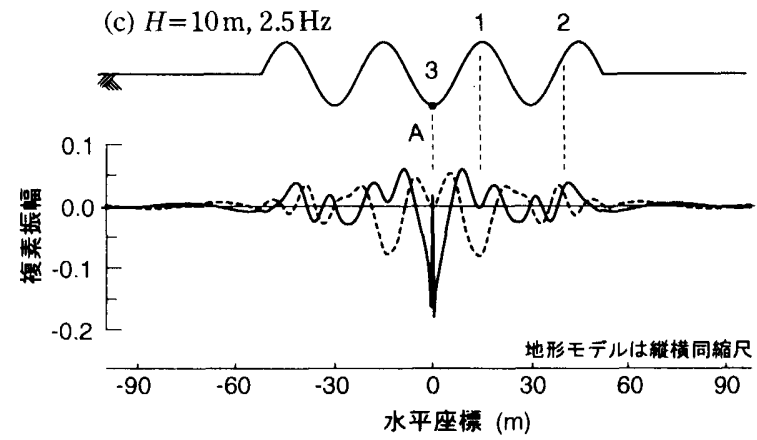

图 5 基本振動数における谷底 (A 点) 一の散乱波の寄与分布

させた場合の谷底の态答関数，(e)〜 (h) 梳山頂の応答関数である. 谷底の念答関数について見ると，高さが $2 \mathrm{~m} の$ 場合には态答関 数が $0 \sim 3$ 程度にあり，3 $\mathrm{Hz}$ 付近の極小值以外の極值は顕著なもの で汭ない，しかし，芯答関数け小さな変化はより高い起伏を持つ地 盤の夋答関数と其通の特徵を持って抢り，例えば，(a) $2 \mathrm{~m}$ におう る3〜7 Hzにあるピークは, (b) $5 \mathrm{~m}$ の場合の $2.5 \sim 5.5 \mathrm{~Hz}$ ，(c) $7 \mathrm{~m}$ の場合の 2〜 $5 \mathrm{~Hz}$ のピーク, そして (d) $10 \mathrm{~m}$ の場合の $1.5 \sim 5 \mathrm{~Hz}$ の つのピークのように, 低振動数方向八移動しながら, より鋭い 形状に変化していく様子と一つのピークに分離していく様子がわ かる。そして，例えば，高さが $5 \mathrm{~m}$ の場合では， $3.0 \mathrm{~Hz}, 7.0 \mathrm{~Hz}$, $10.5 \mathrm{~Hz}$ に执て応答関数は欇大值を示しており, 最初のピークを 亦す振動数（以降では，山頂，谷底に拘らず，それぞれの点におい てピークを示寸最小振動数をその点の「基本振動数」と呼ぶ）か らほぼ等間隔でピークが現れることがわかる。

\subsection{2 山頂での応答関数}

図 4(e)-(h)の山頂の応答関数を見ると, 谷底の場合と同様に忘 答関数が極大・極小となる振動数が存在し, 起伏の高さの変化に対 する卓越振動数の変化も見られる。しかし，谷底の場合とは異な り, 極小值が余り顕著でないために極大值と極小値の差が小さく, 広い範囲の振動数で一様に比較的大きな応答を示すことが特徵的 である。

細かく応答関数の変化を見ると, 低振動数帯においては, 例え ば (e) $2 \mathrm{~m}$ の場合の $3 \mathrm{~Hz}$ 付近のピークが, (f) $5 \mathrm{~m}$ の場合の $2.5 \mathrm{~Hz}$ 付近のより高いピークに推移する様子が見られるが, それ以上起伏 の高さを増加させても応答関数のピークの値はあまり変化してい ない，才なわち，低い起伏のうちに応答関数の極大值は頭打ちと なり, 振動数だけが谷の場合と同様に小さくなる.一方, $5 \mathrm{~Hz}$ 以 上の高振動数帯では起伏が高くなるにつれて全体的に応答振幅が 大きくなっており, 起伏が高くなるほどより広い範囲の振動数帯で 
(a) $3.0 \mathrm{~Hz}$ (波長 $33.3 \mathrm{~m}$ )

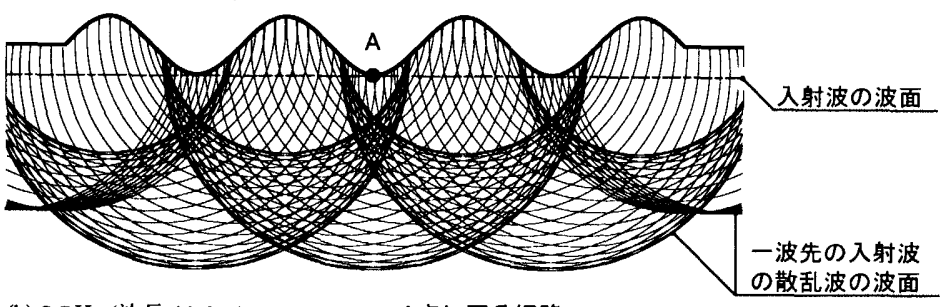

(b) $3.5 \mathrm{~Hz}$ (波長 $28.6 \mathrm{~m}$ )

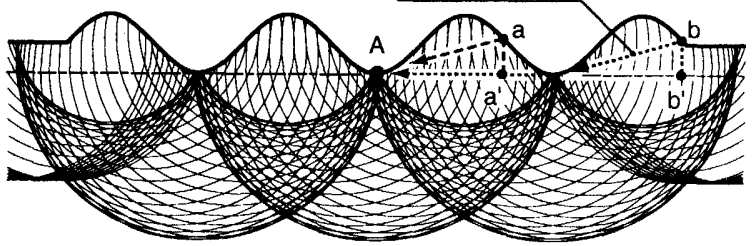

(c) $4.0 \mathrm{~Hz}$ (波長 $25.0 \mathrm{~m}$ )

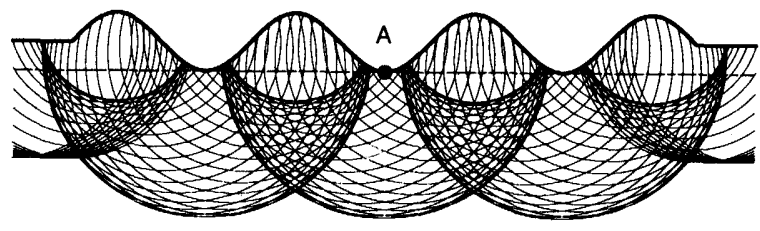

(d) $5.0 \mathrm{~Hz}$ (波長 $20.0 \mathrm{~m}$ )

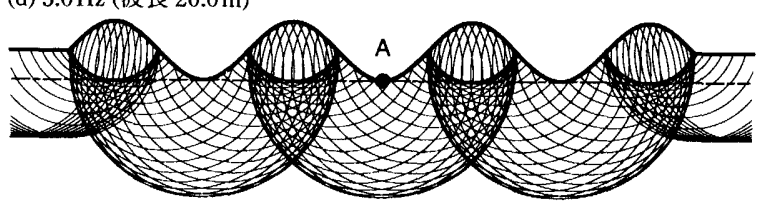

図 6 谷底（A 点）に平面波が入射した時刻において，一波先の入射波によって生じる散乱波が形成する波面

絴横同編尺

大きな応答を示すように変化することがわかる.

\section{3 谷底での応答に寄与する散乱波の分布 \\ 4.3.1 散乱波の寄与分布}

図 5 はA 点に対する散乱波の寄与分布を示したもので，着目す る境界要素 $j$ を $\mathrm{A}$ 点に選び, この点に対する散乱波の寄与を考え る要素 $m$ の $x$ 座標を横軸に用いて散乱波の寄与 $\hat{S}_{j m}$ (式 (10) 参 照) をプロットしたものである. 図 5 の (a)〜(c) は起伏の高さが $2 \mathrm{~m}, 5 \mathrm{~m}, 10 \mathrm{~m}$ それぞれの場合の基本振動数 [図 4 より (a) $4.2 \mathrm{~Hz}$, (b) $3.2 \mathrm{~Hz}$ ，(c) $2.5 \mathrm{~Hz}$ におおる散乱波の寄与分布を示している．な お，散乱波の位相は入射波が着目点 $\mathrm{A}$ 点で最大値 1 をとるときの ものである。

図 5 (a)（高さ $2 \mathrm{~m}$ ）を見ると，図中の $1 ， 2$ 付近と A 点の周囲 （図中 3）からの寄与が大きいことがわかる。 また，図 5 (b)，(c) の ように起伏の高さが増加した場合には，(a)の場合と同様の傾向な がら，寄与分布の形状はやや複雑な形に変化し，值も若干増加す ることがわかる．また 3 つの場合を通して，A 点はその周囲（図 中3）の点から強い寄与を受けており，この寄与の実部が負である ことから入射波の振幅を打ち消すように A 点に作用することがわ かる.

\subsection{2 ホイヘンスの原理に基づく散乱波の干涉}

ホイヘンスの原理では，波面の各点から円筒波で伝播ずる要素 波の包絡線によって次の波面が形成されると解积される. 従って, 起伏のある地盤の忍答は，地表面で散乱された要素波同士，ある いは入射波と要素波の干涉によって説明できると考えられる，図 6 はこの考え方に従い，入射波の波面が A 点にあるときに，地表面 に一波先に入射された波動が形成する散乱波の波面（要素波の包 絡線）の位置を求めたものである.なお，用いた地形モデルは標準 モデル（図 2）のものである.

起伏の高さが $5 \mathrm{~m}$ の場合, 図 4 (b) に示すように, 振動数が 3 $4 \mathrm{~Hz}$ の範囲の応答関数が大きくなっている. 図 6 で振動数が 3 $4 \mathrm{~Hz}$ である場合 $[(\mathrm{a}) \sim(\mathrm{c})]$, ，波先の散乱波の波面は $\mathrm{A}$ 点の付近 にあることがわかる。このように，基本振動数においては，入射波 と, 向かい合う斜面で散乱された一波先の散乱波との増幅的干涉 によって応答が大きくなることがわかる，一方，このような起伏内 部での散乱波（反射波）と入射波の増幅的な干涉は起伏自身が持 つ固有振動々関連すると考えられる，従って，起伏の高さによる基
本振動数の違いは，それぞれの起伏の固有振動数の違いに相当す るものと考えられ，両者の関連性の検討は興味深いテーマである. しかし，A点のように谷底の場合，どのような振動モード形がこの 点の応答を支配するのか自体が不明である，従って，これらの基本 振動数と固有振動との関連については新たな理論展開が必要と考 えられるため, 今後の課題としたい.

上述と同様の增幅的干涉はさらに隣の起伏からも生じる。例え ば，図6(b)に示すように, a'-a-A 点の経路の道のりは約 $28 \mathrm{~m}$ で あるため，入射波の波長が $28 \mathrm{~m}(3.6 \mathrm{~Hz})$ に近い場合に前述のよ うに干渉を生じるが， b’-b-A 点の道のりも約 $58 \mathrm{~m}$ （前述の経路 のほぼ倍）となるため，b 地点に二波先に入射し散乱された波面 も $\mathrm{A}$ 点における入射波と増幅的干涉を生ずる，なお， a 点，b点は 斜面上の特別な一点ではなく，A 点が向かい合う斜面上の点を代表 している.これらの点では図 5 (b) の上うに，比較的大きな寄与分 布を示している。このように谷底に执いては，入射波と周囲の向 かい合った斜面からの散乱波との干涉によって, 特定の振動数の地 震動が增幅されるものと理解できる．以上のようにホイヘンスの 定理によって，起伏によって生じる散乱波の干渉を検討することが 可能である，本定理はさらに，波動場の評価方法としても適用可 能であると考えられるが，定量的な評価を行うためには，方向に よって異なる要素波の振幅の評価方法などを検討する必要がある ため今後の課題としたい.

\section{4 山頂での応答に寄与する散乱波の分布と増幅的干渉}

図 7 は $2.7 \mathrm{~Hz}$ （B 点の基本振動数・図 4 (f) 参照）に打引る，B 点への散乱波の寄与分布を示したものである。散乱波の位相は B 点におけ沙る射波の振幅が最大値 1 をとるときのものである。こ の図から，B点の応答に大きく奇与する地点は $\mathrm{B}$ 点の周囲（図中 1）と図中 2 の部分であることがわかる。ただし，図中 2 の部分は 隣接寸る部分に正負逆の寄与が見られることから，重祇合わせる と余り大きな奇与は残らないものと考えられる. 一方, B 点の周囲 からの寄与は大きく，かつ，実部が正の奇与であるため， $\mathrm{B}$ 点では この散乱波と入射波が干涉して応答が増幅されることがわかる.

図8は入射波の波面が $\mathrm{B}$ 点にある時に，その入射波によって生 じる散乱波の波面をホイヘンスの原理に基づいて求めたものであ る.この図に示されるように散乱波の波面と入射波の波面は山頂で 接しており，山頂付近で両者が増幅的干涉を起こすことがわかる. 


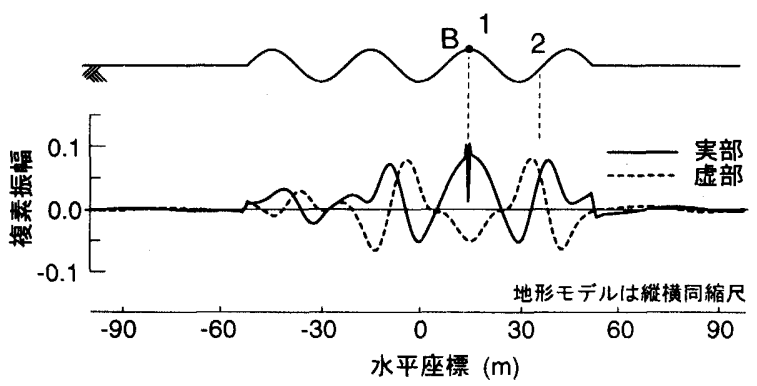

図 7 山頂の基本振動数 $2.7 \mathrm{~Hz}$ にお打る散乱波の寄与分布 $(H=5 \mathrm{~m})$

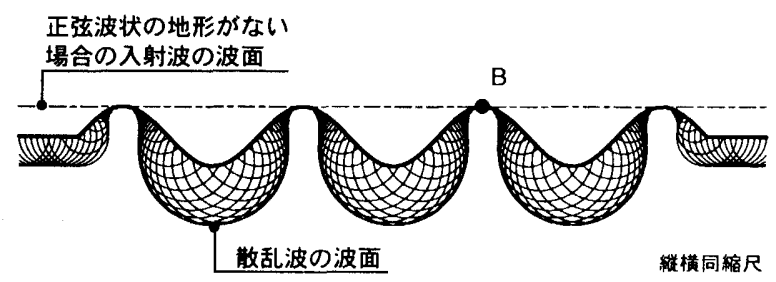

図 8 B 点の入射波ひ波面と同位相の散乱波の波面

また、この現象は入射波と同じ波面の散乱波との干涉であるため， 入射波の波長の違いには余り影響されない。このため，山頂の念 答関数は振動数依存性が小さいものと説明できる.

なお，本節で見たように山頂では增幅の効果が大きいため，基 本振動数を起伏の高さ $H$ と S 波速度 $\beta$ 老朋いて近似的に表現で

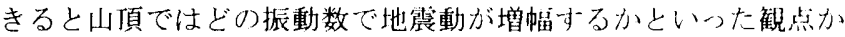
ら工学的に有意義と考えられる。本研究で扱った地形氏デルい最 も簡単な近似モデルは，埥基盤上に湖定された 的くさび状U弹 性体モデルであるう。ここで，くさびの喵さを本研究の地形モデ゙ル

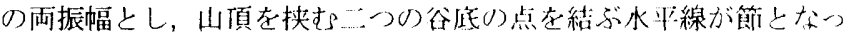
て振動するモード形を想定した場合の湖有振動数を求める ${ }^{21)}$ と， $H=2 \mathrm{~m}, 5 \mathrm{~m}, 7 \mathrm{~m}, 10 \mathrm{~m}$ の場合（図 4(e)〜(h) 参照）に対して，学机 ぞれ, $9.6 \mathrm{~Hz}, 3.8 \mathrm{~Hz}, 2.7 \mathrm{~Hz}, 1.9 \mathrm{~Hz}$ となる。 こり湖有振動数仗 $H=10 \mathrm{~m}$ などの起伏が高い場合には基本振動数にほぼ等しく，上 述の振動モードが現れているものと考えられる。しかし， $H=2 \mathrm{~m}$ などの起伏が低い場合には両者は一致せず，夷際の節はくさびの下 面よりも染い位置にあるものと考えられる。このように，起伏が低 い場合の固有振動については，モード形の検討がまず必要であり， 4.3.2 節で述べた谷底の点の場合と同様に新たな理論展開が必要と 考えられるため, 今後の課題としたい.

\section{5 起伏の数が地震応答に与える影響}

\section{1 地形モデル}

地表面の起伏の数が地震動の忘答に与える影響を検討寸るため に, 起伏の高さを $5 \mathrm{~m}$ に固定し, 不整形部分が谷地形のみでそれ 以外は平坦である正弦波 0.5 波長分の地形モデル，複数波長分の地 形モデル，地表面全体が正弦波形状の地形モデルのそれぞれにつ いて解析を行った。入射波や $\mathrm{S}$ 波速度などの条件は全てこれまで と同じである.

\section{2 応答関数の概観}

図 9(a) は 0.5 波㞽モデル（谷地形のみ）の応答関数を示してい る. この地形モデルの場合, 谷の応答関数は 2 4 $\mathrm{Hz}$ で 2 前後か それ以下，他の振動数ではほぼ 2 を示しておう，地表面形状の影 響は小さいと言ってよい。一方, 図 9(b)の地表面全体が正弦波型
の場合の応答関数をみると, (a) の場合と比べて応答関数の変動が 激しく, また, 全ての点で, 応答関数が $3.3 \mathrm{~Hz}$ 付近とその整数倍 の振動数で顕著な変化が生じていることがわかる，それぞれの応 答関数の形状に着目すると, 谷底付近, 中腹付近, 山頂付近など場 所による形状の違いが見られるが, 谷底では上述の振動数で鋭い ピークを示すこと, 山頂では $2 \sim 10 \mathrm{~Hz}$ 程度の広い範囲で 2 以上の 比較的大きい忘答を示すことなど， 4.1 節で述べた 3.5 波の地形モ デルの場合と同様の傾向を見ることができる。

\section{3 谷底での応答関数}

図 10 は 0.5，1.5，3.5，7.5，11.5 波ならびに地表面全体に正弦 波形状の起伏起配置した地形モデルを用いて，起伏の数と谷底（A 点）に打ける态答関数の関係を調べたものである。

図を見ると，起伏が-一つの谷地形の)みである場合（0.5 波モデル) には応答関数の変化はごく僅かなものであるのに対して, 両側に起 伏が增えるにつれて, 灾答関数は明瞭な極大值（3〜 $4 \mathrm{~Hz}$ の基本振 動数とその整数倍の振動数）を示寸上うに変化することがわかる. 特に (e)(f) など，起伏の数が多い場合には，基本振動数 $(3.3 \mathrm{~Hz}$ 付 近）におけるビークは上り鋭い形状に変化していく，一方，基本振 動数については起伏の数による変化が殆どなく，4節で検討した起 伏の高さ在変化させた場合と極めて対照的である。

\section{4 谷底への散乱波の寄与分布}

网 11 は (a) 11.5 波，(b) 起伏が連続寸る場合について，地形モデ ル中央の谷（A 点）八の散乱波の奇与分布を示したものである。共 に拢動数は基本振動数 $3.3 \mathrm{~Hz}$, 散乱波の位相仗人射波が A 点で最 大值 1 老とるときものである。

図老見る上 (a) (b) 共に A 点办以比較的近距離にある不整形部分

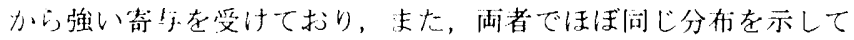
いることが加る。 これに対して，(a) の場合，A点は平坦部分か

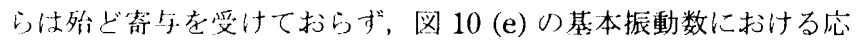
答のビー・クは周囲の（有限の範囲の）不整形部分からの散乱波に 上って念答が增幅された結果であることがおかる。一方，起伏が

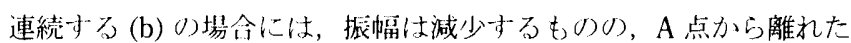
部分からも依然として散乱波の寄与年受けている。またこの範囲 の奇与分布は，谷の点ごとに寄与が小さい同じ形状の分布を繰り 返すものである。このことから，図 10 (f)の鋭いピークは，この， 地表面の起伏の波長と同じ間隔で繰り返し生じる散乱波の干涉に よる可能性を考えることができる。この場合，干涉が生じる条件 は, 起伏の一波長分から散乱された波動と隣の起伏の一波長分か ら散乱された波動が同位相で $\mathrm{A}$ 点に到達する条件，すなわち，地 盤の起伏の波長 $(30 \mathrm{~m})$ が $\mathrm{S}$ 波の波長の整数 $(1,2,3, \ldots)$ 倍にな るという条件である。すなわち，本解析例では $\mathrm{S}$ 波の波長が $30 \mathrm{~m}$ ， $15 \mathrm{~m}, 10 \mathrm{~m}, \ldots$ の場合，才なわち， $\mathrm{S}$ 波速度 $\beta=100 \mathrm{~m} / \mathrm{s}$ 上り，振 動数が $3.3 \mathrm{~Hz}, 6.7 \mathrm{~Hz}, 10 \mathrm{~Hz}, \ldots$ の場合という条件である.この值 は図 $10(\mathrm{f})$ のビークを与える振動数とよく一致しておうり，図 $10(\mathrm{f})$ のピークは地表面の起伏の波長と同じ間隔で繰り返し生じる散乱 波の干渉によるものであることがわかる。なお，この干渉による 鋭いピークは遠く離れた起伏からの散乱波も影響して抢り，起伏の 高さや波長が場所によりばらつく現実の地盤では生じにくいと考 えられる。

また,この起伏間の干涉現象は起伏の波長と地震波の波長だけ で決まるが，4.2.1 節において述べた起伏の高さによる基本振動数 の変化についての説明と矛盾するものではない，起伏の高さによ 
(a) 谷地形の夕の場合

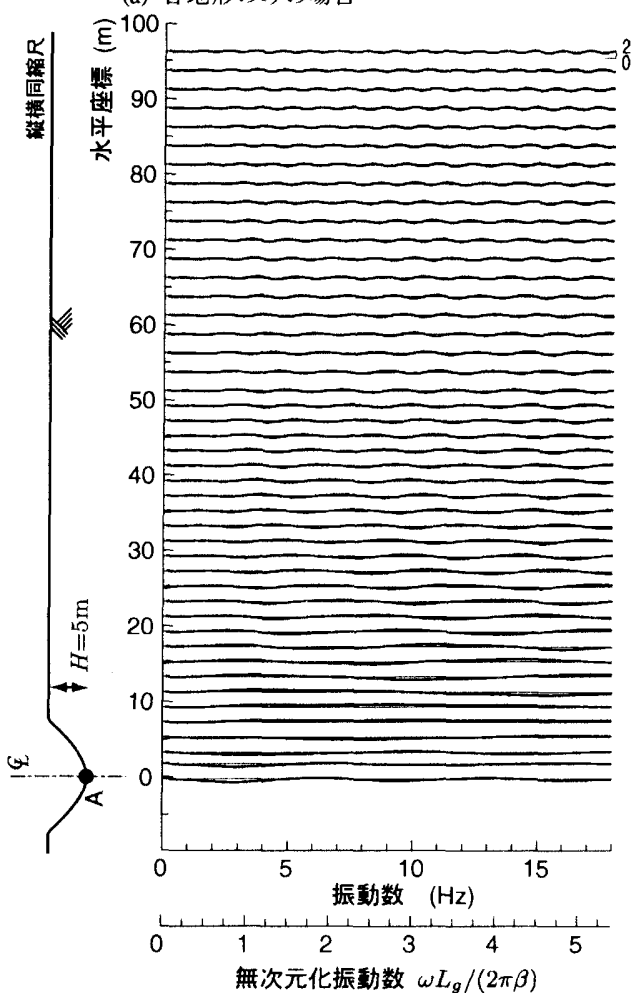

(b) 起伏が続く場合
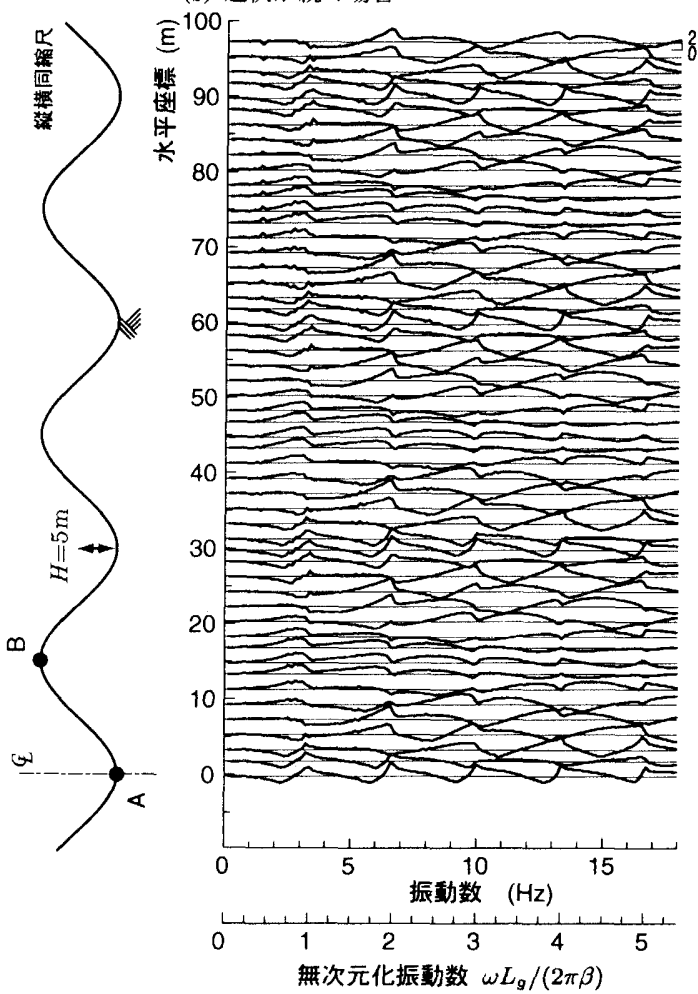

図 9 地表面の各地点の振動数态答関数
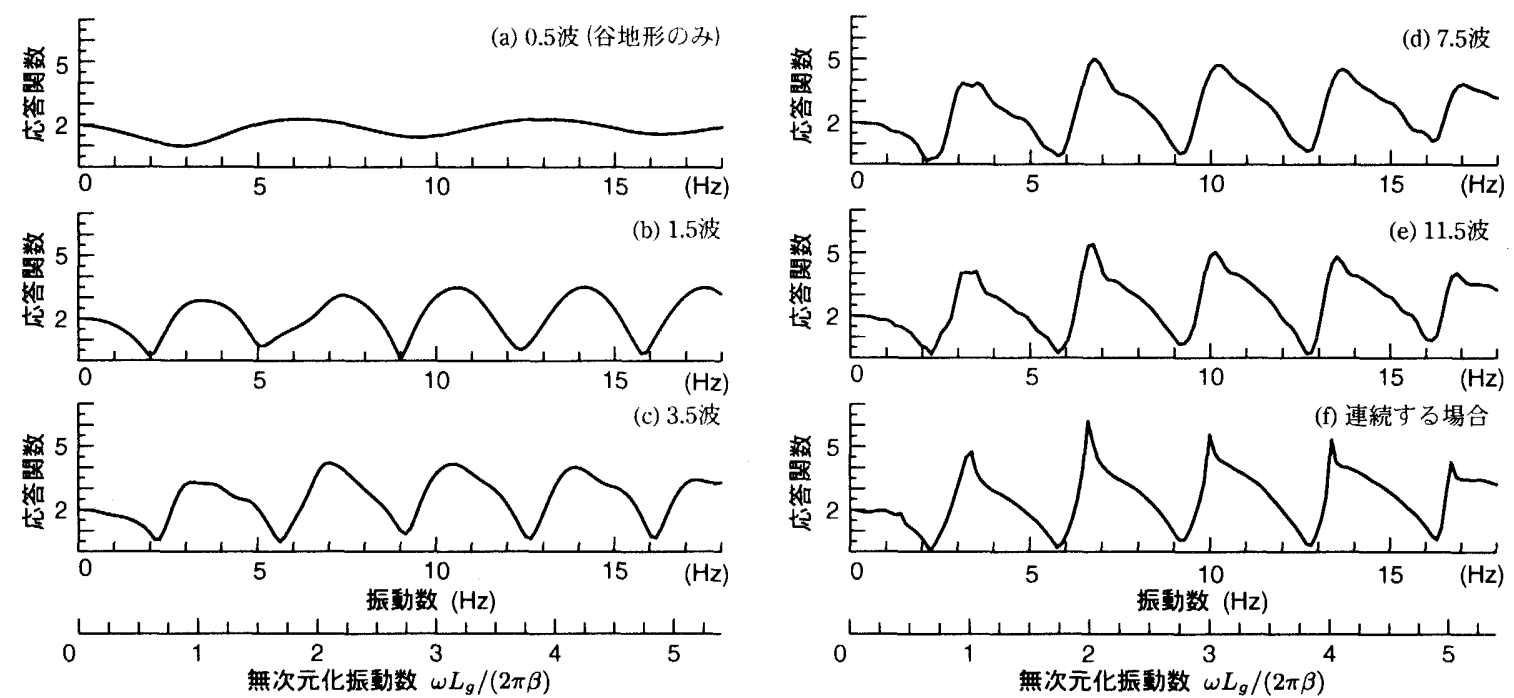

図 10 谷底 (A 点) に㧍ける起伏の数の違いによる応答関数の変化

る基本振動数の変化は一つ（あるいはごく周囲の数個）の起伏内 での干涉の結果（あるいは起伏の高さの固有振動数への影響）で あるのに対して，本節で論じた干渉は連続する起伏のそれぞれか らの散乱波の干涉の結果であり, 両者では干涉する波動が異なって いる. 従って, たとえば起伏が高く（従って, 起伏内での干涉の影 響が強くなる)，かつ連続する場合には両者の干涉の影響が共に現 れるものと考えることができる. 図 12 は連続する起伏の高さを 2 $\sim 10 \mathrm{~m}$ まで変化させた場合の谷底（A 点）の忘答関数を示したも のである (高さ $5 \mathrm{~m}$ の場合は図 10 (f) 参照). 図 12 を見ると, 起 伏が低い場合には連続する起伏の影響が強く, 鋭いピー-ークが現れて
いるのに対し, 起伏が高くなると 3.5 波分の起伏を有する場合（図 $4(\mathrm{c})(\mathrm{d}))$ と似た形状を示すと同時に, 連続ずる起伏による干涉の 結果である鋭いビークも現れており（図 12 (b) $6.7 \mathrm{~Hz} ，(\mathrm{c}) 10 \mathrm{~Hz}$ な ど），二種類の干渉が生じることがわかる.

\section{6 結論}

本研究では，山地ばかりでなく平野部にも多く存在するような 比較的緩やかで連続する起伏がその地震応答に及ぼす影響を検討し た。その方法として, 正弦波形の起伏を有する地形そデルを用い, 起伏の高さと数を変化させてそれぞれの地形モデルの各地点での 态答関数を求め, その性質をパラメトリックに検討した。ささに， 
(a) 11.5 波の場合

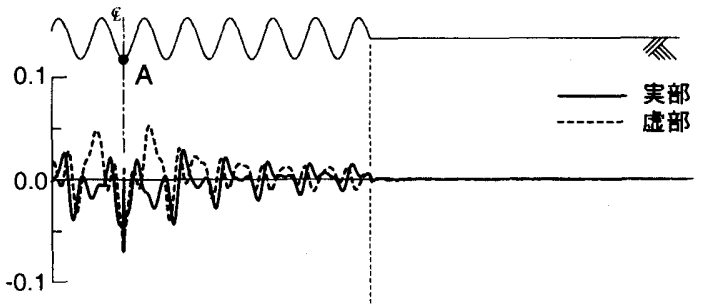

（b）連続する場合

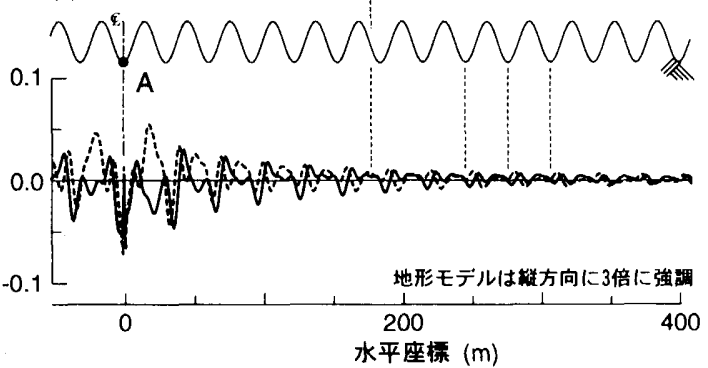

図 11 谷底（A 点）の基本振動数 $3.3 \mathrm{~Hz}$ における $\mathrm{A}$ 点への散乱 波の寄与分布［起伏が (a) 11.5 波の場合，(b) 連続する場合］
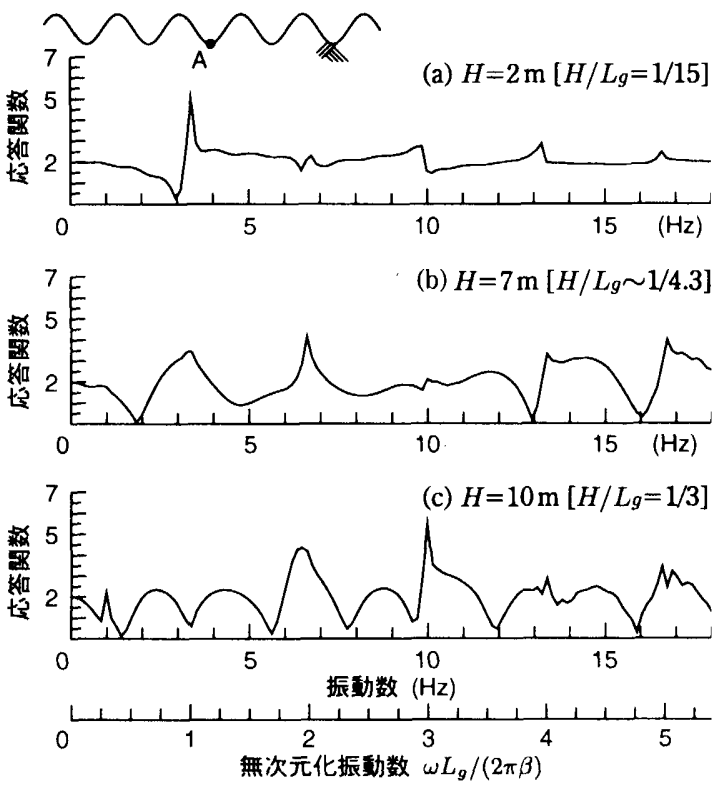

図 12 起伏が連続する場合の谷底（A 点）の态答関数

ホイヘンスの原理に基づく散乱波の波面の位置と，新たに尊人し た寄与分布に基づく散乱波の振幅を検討寸ることにより，各地点で 地震忘答が異なるメカニズムについて考察した，以下に本研究に よって得られた知見を列挙する。

起伏の高さを変化させた場合の検討から，以下の点を指摘した。

1）起伏が高い場合に，谷底での応答関数は振動数に強く依存寸る 複雑な形状を示し，一方，山頂では広い範囲の振動数で大きな 応答を示す。

2）忘答関数の最も低振動数のピーク振動数（基本振動数）は起伏 が高くなるほど低下する，また，応答関数のピークは基本振動 数のほほ整数倍で現れる.

3）基本振動数仗起伏が高くなるほど低下する.

4）谷底での基本振動数とその整数倍の振動数における増幅は，こ の点に面した斜面で散乱された波動の増幅的干渉によるもので
ある。

5）山頂におろける広い範囲の振動数で現れる増幅は, 主に山頂の周 囲の点に入射した波動による散乱波と入射波そのものの干涉に よるものである.これは同一波面間の干涉であるために地震波 の波長には影響されず，応答関数は振動数に余り依存しない.

次に, 起伏の高さを固定し, 起伏の数を変化させた場合の検討 から以下の点を指摘した。

6）起伏の数が増えた場合においても, 起伏が高くなった場合と同 様に, 谷底では応答関数が強く振動数に依存して複雑な形状を 示し, 山頂では広い範囲の振動数で全体的に大きい态答を示す。

7）基本振動数は起伏の数が変わっても殆ど変化しない.

8）谷底では, 起伏の数を増やすと基本振動数におうける増幅が顕著 になり，応答関数の形状は鋭いピークを示すように変化する.

9）8）で述べた応答の鋭い形状のピークは，連続した起伏のそれぞ れから放射される散乱波の增幅的干涉によるもので, 起伏の波 長が地震波の波長の整数倍になる場合に生じる.

\section{考文献}

1）多賀直恒：地盤震動に㧍汸る地形・地盤の不整形性の影響，第 10 回地盤震 動シンボジウム，pp.45-56， 1982.4.

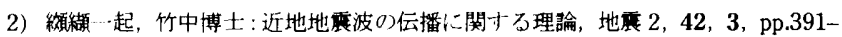
403, 1989. 9

3) Aki, K. and Larner, K. L.:Surface motion of a layered medium having an irregular interface due to incident SH waves, J. Geophys. Res., 75, 5, pp.933-954, 1970. 2.

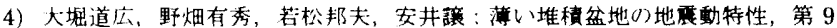
[回日本地震工学シンボジウム，1，pp.181-186，1994.12.

5）神田克久：不整形な層境界を有求石地盤の增幅特性，日本建築学会構造系論 文集，514，pp.119-126，1998. 12 .

6）山中徽，昔原長，武村雅之：堆皘盆地直下に位置对る震源断層に上る盆地内の 3 次元地盤总答，第 10 回日本地莀工学シンボジウム,1,pp.771-776,1998.11.

7) 时中清和，栗本修，福和伸夫，西阪理永，江尻㜔跼：灌尾平野り深部不整形構

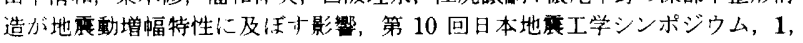
pp.863-868, 1998.11 .

8) Bard, P. Y. and Bouchon, M. : The seismic response of sediment-filled valleys. Part 1. The case of incident SH waves, Bull. Seism. Soc. Am., 70, 4, pp.1263$1286,1980.8$.

9）永野正行：2 次元盆地端部構造 棈造系論文集, 552, pp.85-92, 2002.2.

10) Boore, D. M. : A note on the effect of simple topography on seismic SH waves, Bull. Seism. Soc. Am., 62, 1, pp.275-284, 1972. 2.

11）小牧昭三，毎熊輝記，音田功：崖の近傍に打ける振動特性一SH 波による実 験一、第 7 回自然災害シンボジウム, pp.45-48, 1970. 10.

12）小堀鋝二，篠崎祐三：不整形地盤の振動特性，地震 2，30，2，pp.127-142， 1977.

13) Ohtsuki, A. and Harumi, K. : Effect of topography and subsurface inhomogeneities on seismic SV waves, Earthq. Engng. Struct. Dyn., 11, 4, pp.441$462,1983.7$.

14）八幡夏恵子, 佐々木透 : 表層地盤の非線形性と地形の增幅特性への影響, 第 10 回日本地震工学シンポジウム, 1, pp.995-998, 1998.11.

15）上杉真平，大津政康：境界要素法におりる半無限弹性体における二次元波動 場の解析，土木学会論文集，374/I-6, pp.457-465, 1986.10.

16) Kawase, H, : Time-domain response of a semicircular canyon for incident SV, $P$, and Rayleigh waves calculated by the discrete wavenumber boundary element method, Bull. Seism. Soc. Am., 78, 4, pp.1415-1437, 1988.8.

17) Bouchon, M., Schultz, C. A. and Toksöz, M. N. : Effect of three-dimensional topography on seismic motion, J. Geophys. Res., 101, B3, pp.5835-5846, 1996. 3.

18）田中正隆, 松本敏郎, 中村正行: 計算力学と CAE シリーズ 2 境界要素法, 培風館，1991，7.

19）加川幸雄 : 開領域問題のための有限／境界要素法, サイエンス社，1983.7.

20）小林昭一編著：波動解析と境界要素法, 京都大学学術出版会, 2000.2.

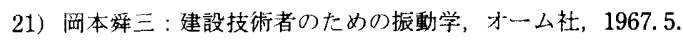

